\title{
Study of Nasal Height for Sexual Dimorhism in 18-30 Years age Group People in Bhavanagr City of Gujarat
}

\author{
Sapana B. Shah ${ }^{1}$, Sanjay Chavada ${ }^{1}$ \\ ${ }^{1}$ Assistant Professor, Department of Anatomy, Faculty of Dental Science, D.D. University, Nadiad, Gujarat.
}

\section{Abstract}

Introduction: Nasal parameters are important for estimation of stature, gender identification and age estimation. Commonly used Nasal parameters are Nasal height, Nasal breadth and Nasal width; Nasal height is one of the most reliable of which. Previous studies have reported racial differences and geographical variation in Nasal height along with importance in gender differentiation. This study was conducted with aim to measure Nasal heights of Bhavangar city population and check for Nasal height differences among males and females. Subjects and Methods: 510 subjects (243 male and 267 female) were enrolled in the present cross-sectional study, conducted at Government Medical College, Bhavanagar in 2011 after institutional ethical committee approval. Age group of the subjects enrolled in the study was 18 to 30 years. Nasal height was measured with the help of sliding caliper after informed and written consent of the subject. The data was compiled and analyzed with standard statistical methods by Microsoft excel and Epiinfo 7.0TM software. Results: Difference in mean nasal height of Males $(46.241 \pm 3.518 \mathrm{~mm})$ and females $(43.799 \pm 3.419)$ was statistically significant at $95 \%$ confidence interval $(\mathrm{p}$ value $=0.0001$ ). Conclusion: Nasal height can be used as one of the parameters for gender determination of the subject.

Keywords: Demarcating point, Gender dimorphism, Nasal parameter, Nasal height.

Corresponding Author: Dr. Sanjay Rameshbhai Chavda, Assistant Professor, Department of Anatomy, P.D.U. Government Medical College, Rajkot, Gujarat.

Received: March 2019

Accepted: March 2019

\section{Introduction}

Anthropometry is a systematized measuring technique to express quantitatively the dimensions of the human body and skeleton. ${ }^{[1,2]}$

Nasal parameters like Nasal height, Nasal breadth and Nasal width are used for racial identification, stature recognition, age determination as well gender differentiation. Nasal height is one of the most reliable parameters. ${ }^{[2-5]}$ Previous studies have reported racial differences and geographical variation in Nasal height along with importance in gender differentiation. ${ }^{[6-9]}$ Nasal height increases upto the age of 18 years, for 18-30 years the nasal height gains it maximum value; after 30 years of age change in the nasal height remains insignificant. ${ }^{[10]}$ Present study was conducted to measure Nasal height in 18-30 years age group of adult living humans in Bhavanagar city of Gujarat and to check for Nasal height differences among males and females.

\section{Aim and Objectives}

Present study was conducted with the aim to find out the role of Nasal in gender differentiation in 18-30 years age group living adult humans of Bhavanagar city. Objective of the study was to measure nasal height, to identify nasal height difference among males and females, and establishing demarcation point for gender differentiation.

\section{Subjects and Methods}

This cross-sectional was conducted at Government Medical College, Bhavanagar in Gujarat after institutional ethical committee approval.

\section{Subject selection}

510 subjects (243 males and 267 females) were enrolled in the study after informed and written consent in proforma approved by institutional ethical committee; consent form was both in English and vernacular language.

Age range of the subjects was 18-30 years; the subjects born in Bhavanagar only were selected from relatives of patients visiting the hospital and medical students studying in the institute during 1st January 2011 to 30th June 2011. Subjects were selected by systemic randomized selection method. The subject born out of the Bhavanagar or not residing in the Bhavnagar were excluded from the study. Subjects enrolled in the study were healthy and without any obvious craniofacial abnormalities like congenital, developmental or acquired through any form of trauma and had no history of plastic or reconstructive surgery. Subject with any of the known otorhinolaryngology disease or respiratory tract disease were not included in the study. 


\section{Paramateres measurement methods}

The subject was asked to sit in a chair in a relaxed position keeping the mouth closed and teeth in central occluded position and head in anatomical position Nasal height: Minimum distance between Nasion and Pronasale was measured in millimeters with sliding Vernier caliper. Each parameter was measured thrice and measurements were repeated by two independent observers, mean of these observations was taken as a final reading to nullify any intra and inter-observer error.

\section{Data compilation and analysis}

Data was entered and compiled in Microsoft excel 2010 and analyzed for the objectives by standard statistical formulas with the help of Epiinfo 7TM software. 95\% confidence interval and $\mathrm{p}$ value $<0.05$ was considered for statistical formulas and methods.

\section{Results}

510 subjects including 243 males and 267 females of 18-30 years of age group born in Bhavanagar city were included in the study.

Mean nasal height was $44.9770 \mathrm{~mm}$ with standard deviation $3.6620 \mathrm{~mm}$. Minimum Nasal height $34.6 \mathrm{~mm}$ was of a 21 years old male while maximum Nasal height $57.0 \mathrm{~mm}$ was of a 20 years old male.

Table 1: Statistical values and Gender wise nasal height

\begin{tabular}{|l|l|l|}
\hline Parameters & Male $(\mathbf{n}=\mathbf{2 4 3})$ & Females $(\mathbf{n}=\mathbf{2 6 7})$ \\
\hline Range & $34.6-57.0$ & $35.3-51.1$ \\
\hline Mean & 46.241 & 43.799 \\
\hline S.D. & 3.518 & 3.419 \\
\hline $\begin{array}{l}\text { Calculated Range } \\
\text { (Mean } \pm \text { 3SD) }\end{array}$ & $35.687-56.795$ & $33.542-54.056$ \\
\hline Demarcating Point & $>54.056$ & $<35.687$ \\
\hline $\begin{array}{l}\text { \% \& no. identified by D.P* } \\
\text { (True positives) }\end{array}$ & $2(0.82 \%)$ & $1(0.411 \%)$ \\
\hline $\begin{array}{l}\text { False positive subjects } \\
\text { identified by D.P. }\end{array}$ & 0 & 1 \\
\hline $\begin{array}{l}\text { P value=0.0001, Confidence Interval 95\%, Two tailed T-test for unpaired } \\
\text { groups; } \\
\text { *D.P= Demarcating point }\end{array}$ & \multicolumn{2}{|l}{} \\
\hline
\end{tabular}

Difference in male and female nasal height was statistically significant at $95 \%$ confidence interval $(\mathrm{p}$ value $=0.0001<$ 0.05, [Table 1]).

Demarcation point analysis: Calculated range (Mean \pm 3 SD) of nasal height for male was $35.687-56.795 \mathrm{~mm}$ and demarcating point was $>>54.056 \mathrm{~mm}$ by which 2 subjects could be identified correctly.

Calculated range (Mean $\pm 3 \mathrm{SD}$ ) of nasal index for female $33.542-54.056 \mathrm{~mm}$ and demarcating point was $<35.687$ by which 1 subject could be identified correctly.

Out of 510 subjects only 3 subjects could be identified as true positive cased for gender differentiation with demarcation point analysis. One male subject had nasal height was $34.6 \mathrm{~mm}$ which was identified as female (false positive) case for gender identification with demarcating point.

\section{Discussion}

Mean Nasal height of whole sample was $44.9770 \mathrm{~mm}$ with standard deviation $3.6620 \mathrm{~mm}$.

Troncoso PJA et al (2008) reported mean nasal height 50.09 $\pm 5.878 \mathrm{~mm}$ and $46.86 \pm 6.619 \mathrm{~mm}$ for males and females respectively in adult chileno; the nasal height reported in the study is quite higher than the present study. ${ }^{[1]}$ Vidhya CS et al (2012) reported mean nasal $47.9 \pm 5.7 \mathrm{~mm}$ in males and $45.4 \pm 3.5 \mathrm{~mm}$ in females of south Indian population; result of the study conducted upon dry skulls correlates with the result of the present study. ${ }^{[9]}$

Nasal heights of previous studies variates depending on the geographical and racial origins; but the result of the current study correlated with the study conducted in Indian region [Table 2]. The difference among various population may be due to environmental effect and stature variation; comparison with the study of different population shows Nasal height of the Bhavanagar city population is lower than that of European, American and African population while comparable with south-east population.

Table 2: Comparison of Nasal height between different studies and present study

\begin{tabular}{|c|c|c|c|c|c|}
\hline \multirow{2}{*}{$\begin{array}{l}\text { Sr. } \\
\text { No. }\end{array}$} & \multirow[t]{2}{*}{ Study } & \multirow[t]{2}{*}{ Race } & \multirow{2}{*}{$\begin{array}{l}\text { Sample } \\
\text { size }\end{array}$} & \multicolumn{2}{|c|}{ Nasal Height (mm) } \\
\hline & & & & $\begin{array}{l}\text { Male } \\
\text { (Mean } \\
+ \text { SD) } \\
\end{array}$ & $\begin{array}{l}\text { Female } \\
\text { (Mean } \\
+ \text { SD) }\end{array}$ \\
\hline 1 & $\begin{array}{l}\text { Farkas et al, }{ }^{[12]} \\
\text { (1987) }\end{array}$ & Indian & - & $\begin{array}{l}47.2+ \\
03.7 \\
\end{array}$ & $\begin{array}{l}43.7+ \\
03.6 \\
\end{array}$ \\
\hline 2 & $\begin{array}{l}\text { Troncoso PJA } \\
\text { et al, }{ }^{[11]}(2008)\end{array}$ & Chileno & 180 & $\begin{array}{ll}50.09 & \pm \\
5.878 & \end{array}$ & $\begin{array}{l}46.86 \pm \\
6.619\end{array}$ \\
\hline 3 & $\begin{array}{l}\text { Ngeow WC et } \\
\mathrm{al}^{[13]}(2009)\end{array}$ & $\begin{array}{l}\text { Malaysian } \\
\text { Indian }\end{array}$ & 100 & $51.9+3.6$ & $\begin{array}{l}50.4+ \\
3.2\end{array}$ \\
\hline 4 & $\begin{array}{l}\text { Sforza C et } \\
\mathrm{al},{ }^{[10]}(2010)\end{array}$ & Italians & 192 & $\begin{array}{ll}55.65+ \\
3.31\end{array}$ & $\begin{array}{l}51.17+ \\
3.5\end{array}$ \\
\hline 5 & Present Study & $\begin{array}{l}\text { Bhavangar } \\
\text { (Indian) }\end{array}$ & 510 & $\begin{array}{l}46.2414+ \\
.518\end{array}$ & $\begin{array}{l}43.799 \\
+3.419\end{array}$ \\
\hline
\end{tabular}

Present study reported difference in male and female Nasal index was statistically highly significant ( $\mathrm{p}$ value $=0.0001$, 0.05 ), the nasal height of female was significantly low than that of males which indicates females of Bhavanagar city has shorter nose than males. The difference in Nasal height may be due to difference in stature also as reported by previous studies. ${ }^{[13,14]}$ Holton $\mathrm{Ne}$ et al (2016) also found difference male and female nasal height in relation to sitting height. ${ }^{[15]}$ Vidhya CS et al (2012) also reported Nasal height as an independent variable for gender determination. ${ }^{[9]}$

Demarcation point analysis in the present study did not show higher predictive value, no previous authentic study was available to compare the demarcation point analysis for nasal height.

\section{Conclusion}

Nasal height can be used as a supportive parameter to determine the gender of the subject. Bhavanagar city population of 18-30 years age range has comparable nasal height with other Indian population. 


\section{Shah d Chawada; Nasal Height far Sexual Dimarhism}

\section{References}

1. Roger W, Peter L Williams, M Dyson, Bannister L H. Gray's Anatomy. 37th edition, London: Elseveir Churchill Livingstone; 1995: $601-612$.

2. Craniometric studies, No.27; A study of the nasal index in representative types of man. American Journal of Physical Anthropology April/June 1930; 14 (2): 293-304.

3. Heidari $\mathrm{Z}$, Mahmoudzadeh $\mathrm{H}$, Khammar $\mathrm{T}$, Khammar $\mathrm{M}$. Anthropometric measurements of external nose in 18-25 years old Sistani and Baluch aborigine women in the southeast of Iran. Folia Morphol;68(2):88 - 92.

4. Khandekar B, Srinivasan S, Mokal N, Thatte MR. Anthropometric analysis of lip - nose complex in Indian population. Indian J Plast surg. 2005; 38(2):128-131.

5. Chimmalgi M, Kulkarni Y, Sant SM. Sexing of skull by new metrical parameters in Western India. Journal of Anatomical Society of India 2007;56(1):1-6.

6. Oladipo GS, Olabiyi AO, Oremosu AA, Noronha CC. Nasal indices among major ethnic groups in Southern Nigeria. Scientific Research and Essay. 2007;2(1):20 -22.

7. Krishan K. Estimation of stature from cephalo-facial anthropometry in North Indian population foren. Sci. Inter. 2008;
181(1-3):52.1-52.6.

8. Franciscus RG. Long JC. Variation in human nasal height and breadth. Am. J. Phys. Anthropol. 1991:85(40);419-427.

9. Vidya CS, Prashantha B, Gangadhar MR. Anthropometric Predictors for Sexual Dimorphism of Skulls of South Indian Origin. International Journal of Scientific and Research Publications. 2012 $2(10) ; 1-4$.

10. Sforza C, Grandi G, Menezes M, Tartaglia GM, Ferrario VF. Ageand sex-related changes in the normal human external nose. Forensic Science International 204 (2010) 205.e1-205.e9.

11. Troncoso, P.JA.,Suazo GIC., Cantín LM, Zavando. MDA. Sexual dimorphism in the nose morphotype in adult Chilean. Int. J. Morphol.2008: 26(3);537-542..

12. Farkas LG, Kolar J C. Anthropometrics and the art of aesthetics of women's faces. Clin Plast Surg 1987;599-615

13. Ngeow WC, Aljunid S.T. Craniofacial anthropometric norms of Malaysian Indians. Indian Journal of Dent Res 2009; 20(3):313 318

14. Umar MBT, Singh R, Shugaba AI. Cephalometric indices among Nigerians. Journal of Applied sciences 2006;6(4):939 - 942.

15. Holton NE, Alsamawi A, Yokley TR, Froehle AW. The ontogeny of nasal shape: An analysis of sexual dimorphism in a longitudinal sample. Am J Phys Anthropol. 2016;160(1):52-61.

Copyright: (C) the author(s), publisher. Academia Anatomica International is an Official Publication of "Society for Health Care \& Research Development". It is an open-access article distributed under the terms of the Creative Commons Attribution Non-Commercial License, which permits unrestricted non-commercial use, distribution, and reproduction in any medium, provided the original work is properly cited.

How to cite this article: Shah SB, Chavada S. Study of Nasal Height for Sexual Dimorhism in 18-30 Years age Group People in Bhavanagr City of Gujarat. Acad. Anat. Int. 2019;5(1):71-73.

DOI: dx.doi.org/10.21276/aanat.2019.5.1.16

Source of Support: Nil, Conflict of Interest: None declared. 